\title{
Important areas at sea for adult loggerhead sea turtles in the Mediterranean Sea: satellite tracking corroborates findings from potentially biased sources
}

\author{
Judith A. Zbinden • Adrian Aebischer • \\ Dimitris Margaritoulis $\cdot$ Raphaël Arlettaz
}

Received: 4 January 2007 / Accepted: 25 October 2007 / Published online: 20 November 2007

(C) Springer-Verlag 2007

\begin{abstract}
Sea turtle populations worldwide suffer from reduced survival of immatures and adults due to fishery bycatch. Unfortunately, information about the whereabouts of turtles outside the breeding habitat is scarce in most areas, hampering the development of spatially explicit conservation plans. In the Mediterranean, recoveries of adult females flipper-tagged on nesting beaches suggest that the Adriatic Sea and Gulf of Gabès are important foraging areas for adults, but such information could be heavily biased (observing and reporting bias). In order to obtain unbiased data, we satellite-tracked seven loggerhead sea turtles after they completed nesting in the largest known Mediterranean rookery (Bay of Laganas, Zakynthos, Greece). Three females settled in the north Adriatic Sea, one in the south Adriatic Sea and two in the Gulf of Gabès area at the completion of their post-nesting migrations (one individual did not occupy a distinct foraging area). The concordance of tracking results with information from recoveries of flipper-tagged turtles suggests that the north Adriatic Sea and the Gulf of Gabès represent key areas for female adult Mediterranean loggerhead sea turtles.
\end{abstract}

Communicated by M. Wahl.

J. A. Zbinden $(\square) \cdot$ A. Aebischer $\cdot$ R. Arlettaz

Zoological Institute, Division of Conservation Biology,

University of Bern, Baltzerstrasse 6, 3012 Bern, Switzerland

e-mail: judith.zbinden@nat.unibe.ch

D. Margaritoulis

ARCHELON, The Sea Turtle Protection Society of Greece,

Solomou 57, 10432 Athens, Greece

\section{Introduction}

Knowledge on the whereabouts of marine animals is generally poor compared to that of terrestrial species or life stages. This is at least in part due to the fact that terrestrial habitats are better accessible to human observers. The lack of spatial information of populations in marine areas often impedes the design of efficient conservation strategies for endangered species. With sea turtles for example, conservation and research activities have traditionally focused on their terrestrial habitat (Schroeder et al. 2003). Population dynamics models have, however, unequivocally revealed the high impact of immature and adult survival rates on the fate of sea turtle populations (Crouse et al. 1987; Heppell et al. 2003). Indeed, changes in mortality rates in these primarily marine life stages are the most likely cause for both rapid decrease and recovery of sea turtle populations (Spotila et al. 2000; Hays 2004). Survival of animals at sea is much reduced due to fishery-related mortality (bycatch) in most if not all extant sea turtle populations (Hays et al. 2003; Lewison et al. 2004). There is thus an urgent need to extend conservation activities beyond the traditional protection of nesting beaches (Crouse et al. 1987). However, the migratory behaviour and ecology of individuals at sea is conjectural at best in most sea turtle populations, hampering an efficient, spatially explicit implementation of mitigation measures.

Traditionally, information on adult migrations has been gained through recovery of individuals flipper-tagged on nesting beaches (e.g. Limpus et al. 1992; Margaritoulis et al. 2003; Troëng et al. 2005). Fishery bycatch reports have also provided hints on the whereabouts of turtles at sea (e.g. Casale et al. 2004). However, flipper-tagging data only provide point-to-point movement information with no details on the exact migration route or whether the point of 
recovery is the animal's destination. Moreover, recovery data may be heavily biased by differences in observing effort and/or tag reporting amongst actual destinations (Schroeder et al. 2003). Data from bycatch reports suffer from similar caveats. Although these two sources can provide valuable information on adult turtle distribution at sea, they might thus not mirror the actual importance of at-sea areas for populations. Monitoring the migrations of individual turtles of a rookery through satellite telemetry seems one feasible way to gain unbiased information on the main whereabouts of the individuals of a population at sea and can thus verify hypotheses based on recoveries of tagged turtles. Satellite tracking of marine turtles has been used to identify migratory pathways and feeding grounds and to study behaviour in the foraging habitat (e.g. Godley et al. 2002a; Godley et al. 2002b; Troëng et al. 2005; Hays et al. 2006; Myers and Hays 2006; McMahon et al. 2007).

Mediterranean loggerhead sea turtle (Caretta caretta) rookeries are demographically independent from Atlantic populations (Bowen et al. 1993; Laurent et al. 1993, 1998) and Mediterranean loggerhead sea turtles have evolved specific adaptations to the distinct Mediterranean environmental conditions (Tiwari and Bjorndal 2000). Although fishing has a long tradition in the Mediterranean Sea, the recent intensification of fisheries has led to turtle bycatch numbers that seem incompatible with the long-term persistence of the already relatively small numbers of loggerhead sea turtles (Laurent et al. 1998; Gerosa and Casale 1999; Lewison et al. 2004).

We studied the at-sea spatial behaviour of adult female loggerhead sea turtles nesting in the Bay of Laganas on the island of Zakynthos (Greece; Fig. 1a), which harbours the largest known loggerhead sea turtle rookery in the Mediterranean Sea, accounting for roughly a quarter of all documented clutches (Margaritoulis et al. 2003). In the Mediterranean, the migratory behaviour of adult loggerhead sea turtles is well-known for the small rookery in northern Cyprus (Godley et al. 2002a; Broderick et al. 2007). This study is the first direct assessment of at-sea spatial behaviour of adult loggerhead sea turtles originating from Zakynthos (a major Mediterranean rookery). A high number of recoveries of turtles flipper-tagged in Zakynthos and the nearby Peloponnesus rookery (42 individuals in the Adriatic Sea and 28 individuals in the Gulf of Gabès area out of a total of 100 recoveries over 18 years) suggests that the Adriatic Sea and the Gulf of Gabès area (Fig. 1a) are hotspots for adult loggerhead sea turtles from these rookeries (Margaritoulis et al. 2003). This view seems to be supported by bycatch information (Laurent and Lescure 1994; Gerosa and Casale 1999; Casale et al. 2004), but an objective appraisal is still lacking. Our main goal was therefore to verify by an unbiased method (satellite tracking) whether the Adriatic Sea and the Gulf of Gabès area indeed represent the two major foraging areas for turtles of the Zakynthos rookery.

\section{Materials and methods}

A total of seven adult female turtles (three in 2004 and four in 2005; Table 1) were equipped with satellite transmitters after they had nested on beaches of the Bay of Laganas, Zakynthos, Greece $\left(37^{\circ} 43^{\prime} \mathrm{N}, 20^{\circ} 53^{\prime} \mathrm{E}\right)$. We attached satellite transmitters (KiwiSat 101; $630 \mathrm{~g}$; Sirtrack Ltd.,
Fig. 1 Migration pathways and individual foraging areas (where applicable) of seven loggerhead sea turtles originating from the Bay of Laganas, Zakynthos (Greece). Individual foraging areas are circled. a Tracks from the six turtles with individual foraging areas. b Migration of the turtle not occupying a distinct foraging area

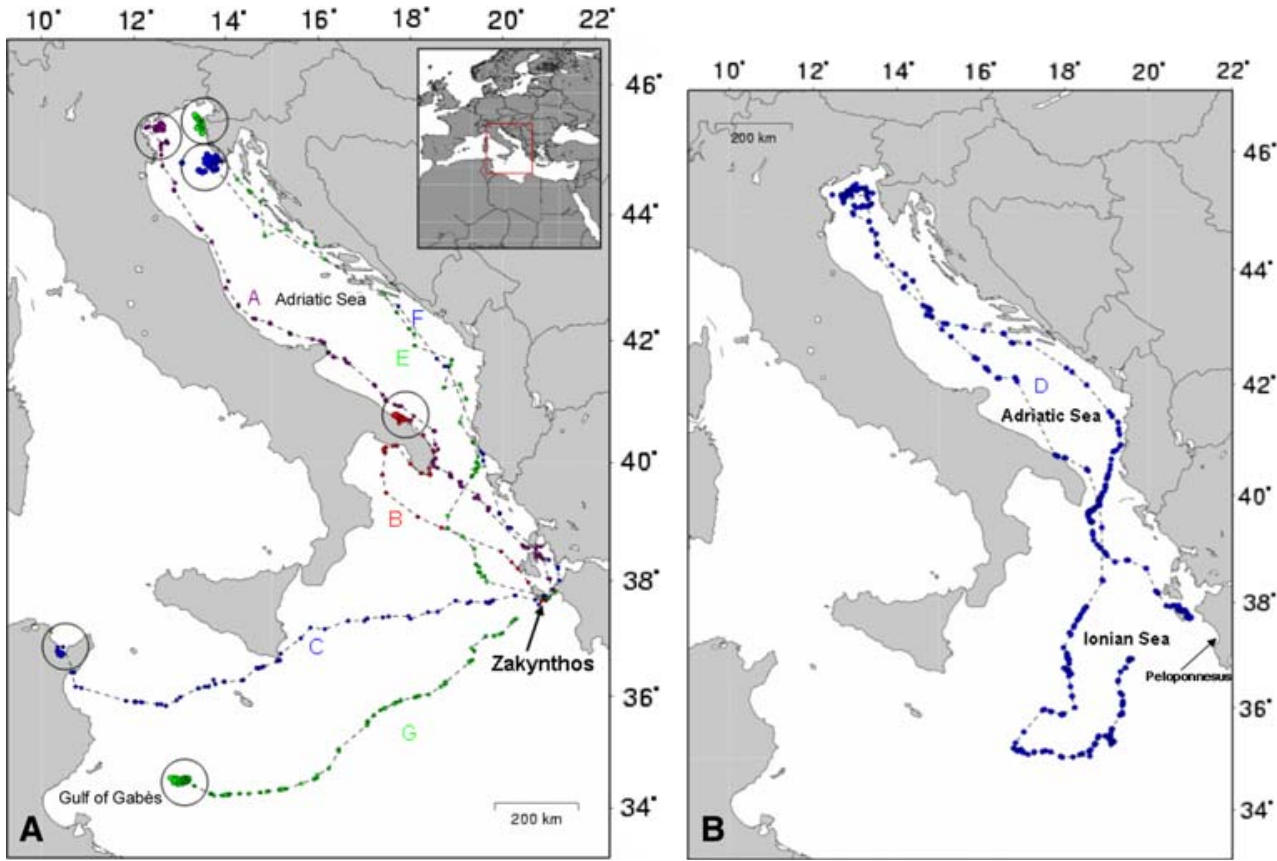


Table 1 Summary data for seven satellite-tracked loggerhead sea turtles originating from Zakynthos

\begin{tabular}{lllll}
\hline Turtle & $\begin{array}{l}\text { CCL } \\
(\mathrm{cm})\end{array}$ & $\begin{array}{l}\text { Transmitter } \\
\text { attachment date }\end{array}$ & $\begin{array}{l}\text { Start of postnesting } \\
\text { migration }\end{array}$ & $\begin{array}{l}\text { Duration of } \\
\text { tracking (days) }\end{array}$ \\
\hline $\mathrm{A}$ & 85 & 27 June 2004 & 11 August 2004 & 130 \\
$\mathrm{~B}^{\mathrm{a}}$ & 86 & 28 June 2004 & 24 July 2004 & $279^{\mathrm{a}}$ \\
$\mathrm{C}$ & 91 & 29 June 2004 & 10 August 2004 & 760 \\
$\mathrm{D}$ & 79 & 16 June 2005 & 29 July 2005 & 189 \\
$\mathrm{E}$ & 87 & 19 June 2005 & 27 July 2005 & 419 \\
$\mathrm{~F}$ & 89 & 21 June 2005 & 8 August 2005 & 392 \\
$\mathrm{G}^{\mathrm{b}}$ & 76 & 10 August 2005 & 10 August 2005 & 118 \\
\hline
\end{tabular}

$C C L$ curved carapace length (notch to tip)

a Turtle B was found stranded on 2 April 2005 with the transmitter still attached. Symptoms indicated she had been trapped in a fishing net (F. Bentivegna, personal communication)

${ }^{\mathrm{b}}$ Refurbished transmitter of individual B

New Zealand) on the second central carapace scute, which was freed from barnacles and cleaned with a pot-scrubber, sandpaper and acetone. We used two-part epoxy resin (Durostick $^{\circledR}$, Durostick, Greece in 2004 and Araldite AW2101, Vantico, Switzerland in 2005) as a fixative. We restrained turtles in a wooden portable corral with their head covered with a piece of fabric during the attachment procedure, which lasted for 1-2 $\mathrm{h}$, depending on the state of the carapace.

Transmitters were programmed for a signal emission every $36 \mathrm{~s}$ with an output power of $1 \mathrm{~W}$. Those purchased in 2004 had duty cycles of 10:10 h (on/off) for 100 days, followed by 10:78 h for the rest of battery life. Equipment acquired in 2005 was programmed to emit continuously for 60 days, followed by a 10:10 h duty cycle for the rest of their life. Transmitters had a salt-water switch to suppress transmissions when submerged. Except for one individual, turtles laid further clutches within the specific nesting season after transmitters were attached (Table 1). All individuals were tracked at least until reaching their individual foraging areas and for several weeks thereafter.

We located turtles through the Argos system (http:// www.argosinc.com) with geolocations being categorized into seven location classes (LCs). According to Argos and confirmed by Hays et al. (2001a), the location errors follow a normal distribution with their standard deviations being less than $1 \mathrm{~km}$ for the three most accurate location classes (LCs 3, 2 and 1 in decreasing accuracy). Argos does not indicate the accuracy of classes $0, \mathrm{~A}, \mathrm{~B}$ and $\mathrm{Z}$, but Hays et al. (2001a) showed that the accuracy of LC A is comparable to that of LC 1 . We therefore disregarded geolocations of LCs $\mathrm{O}, \mathrm{B}$ and $\mathrm{Z}$ unless otherwise stated. Additionally, geolocations requiring an unrealistic travel speed of more than $5 \mathrm{~km} / \mathrm{h}$ (Luschi et al. 1998) were eliminated (typically, this speed filter eliminated less than $10 \%$ of geolocations), although we are aware that elimination of geolocations requiring a speed lower than the actual speed cannot be likewise eliminated and the elimination of unrealistically high speeds might lead to a slight underestimation of actual speed. To minimize differences due to variation in the frequency of geolocations obtained, we used the location with the highest accuracy per day for calculation of distances. If more than one geolocation fulfilled this criterion, the one closest to midday was considered. We divided migration into oceanic (waters above more than $200 \mathrm{~m}$ sea floor depth) and neritic (waters above less than $200 \mathrm{~m}$ sea floor depth) phases. An individual was considered to have reached its main foraging or over-wintering area when movement was no longer directed for at least three consecutive days (movement was considered directed if the trajectory between two locations was less than $45^{\circ}$ off to either side from the extension of the trajectory between the previous two geolocations). We considered the area where a turtle completed its post-nesting migration as this individual's foraging area, although we cannot actually prove foraging. The term "over-wintering area" does not imply to what extent turtles take in food during winter, but most likely their main motivation in leaving the foraging area is temperature and not prey depletion. Only LCs 3, 2 and 1 were used in the individual foraging and over-wintering areas. We calculated home range sizes (minimum convex polygons; containing all geolocations) for individual foraging and over-wintering areas with 10 or more geolocations of LCs 3, 2 and 1.

Data were downloaded and analysed in the Satellite Tracking and Analysis Tool (Coyne and Godley 2005), which provided information about sea surface temperatures (spatial resolution $0.33^{\circ}$; temporal resolution 1 week) and depth of the seafloor $\left(0.05^{\circ}\right.$ resolution $)$ at the turtles' locations. We plotted locations using the MAPTOOL program (http://www.seaturtle.org).

\section{Results}

All individuals left Zakynthos in late July or early August (Table 1). The duration of tracking ranged from 118 to 760 days (Table 1 ). Six turtles showed a clear post-nesting destination: four migrated to the Adriatic Sea (three to the northern and one to the southern part) and two to the area of the Gulf of Gabès in North Africa (Fig. 1a). One turtle (D) did not end its migration once it reached the very northern part of the Adriatic Sea, but resumed its route heading southwards and was constantly on the move (Fig. 1b).

The six turtles covered between 697 and 1,238 km to reach their individual foraging areas. These migrations took them between 19 and 37 days (Table 2). All routes were remarkably straight and directed towards the individual 
Table 2 Post-nesting migrations (distances covered, durations and travelling speeds) of the six satellite-tracked loggerhead sea turtles that occupied individual foraging areas, with respect to phase of migration (oceanic vs. neritic)

\begin{tabular}{llllllll}
\hline Individual & $\mathrm{A}$ & $\mathrm{B}$ & $\mathrm{C}$ & $\mathrm{E}$ & $\mathrm{F}$ & $\mathrm{G}$ \\
\hline Oceanic & Distance $(\mathrm{km})$ & 367 & 475 & 967 & 419 & - & 855 \\
& Duration (days) & 9 & 12 & 22 & 12 & - & 22 \\
& Speed (km/h) & 1.8 & 1.7 & 1.9 & 1.4 & - & 1.7 \\
\multirow{4}{*}{ Neritic } & Distance (km) & 792 & 222 & 75 & 819 & 1072 & - \\
& Duration (days) & 28 & 7 & 4 & 22 & 32 & - \\
& Speed (km/h) & 1.4 & 1.4 & - & 1.5 & 1.4 & - \\
Total & Distance (km) & 1,159 & 697 & 1,042 & 1,238 & 1,072 & 855 \\
& Duration (days) & 37 & 19 & 26 & 34 & 32 & 22 \\
\hline
\end{tabular}

Travelling speed was only calculated for durations of five or more days. For turtles travelling to the North Adriatic Sea, the initial part of the journey within the Ionian Islands was not included for speed calculations because of frequent direction changes

foraging areas (Fig. 1a). Travelling speeds for all individuals on both oceanic and neritic phases of the migration ranged from 1.4 to $1.9 \mathrm{~km} / \mathrm{h}$ (Table 2).

Six individuals occupied spatially well-defined individual foraging areas upon the completion of their post-nesting migrations (Fig. 1a). These individual foraging areas were all situated above the continental shelf, at maximal $40 \mathrm{~m}$ of median sea floor depth and within a maximum of $15 \mathrm{~km}$ from the coast, except for that of turtle G (Fig. 1a, Table 3). Home range sizes ranged from 3.5 to $1,198 \mathrm{~km}^{2}$ with a mean of $305 \mathrm{~km}^{2}$ (Table 3 ).

The four individuals which still yielded location data during winter left their individual foraging areas during the months of October and November to travel to over-wintering areas further south, at a distance of 100 to nearly $1,000 \mathrm{~km}$ from the individual foraging areas (Table 3; Fig. 2). Accurate location information during the winter was, however, only obtained for turtle E. Its over-wintering home range was with $166 \mathrm{~km}^{2}$ smaller than that of its foraging area (Fig. 2a; Table 3). The three turtles (C, E and F) whose transmitters still delivered data the following spring all migrated back to exactly the same individual foraging area that they had occupied after completing their post-nesting migrations (Fig. 2). Turtle $\mathrm{C}$ was tracked during a complete remigration interval. It did not spend the winter preceding nesting in its wintering area of the previous year (Fig. 2b).

Turtle D was constantly on the move and never appeared to occupy a discrete individual foraging area. However, it travelled at a much reduced average speed during the 25 days it spent in the northernmost part of the Adriatic Sea compared to the migration from Zakynthos to the very north of the Adriatic Sea and the journey after it left the very north Adriatic Sea (0.34 vs. $1.6 \mathrm{~km} / \mathrm{h}$ and $0.94 \mathrm{~km} / \mathrm{h}$, respectively) (Fig. 1b). Inferring from these speed data to differences in animal swimming behaviour without correcting for currents might however, be problematic (Gaspar et al. 2006). But because the turtle followed the general current movement in the Adriatic Sea (Zavatarelli and Pinardi 2003), the slow displacement of the turtle in the northern part are likely a result of slow swimming behaviour. Turtle D was tracked for an additional 84 days after having left the north Adriatic Sea, moving into oceanic waters.

\section{Discussion}

Most of the turtles tracked in this study migrated to the north Adriatic Sea or the Gulf of Gabès. Strikingly, these are the two regions where the majority $(70 \%)$ of flippertagged loggerhead sea turtles originating from Zakynthos and the nearby Peloponnesus rookery were reported from Margaritoulis et al. (2003). These results suggest that the two regions represent the main foraging areas for Zakynthian female loggerhead sea turtles, and hence essential areas for a large number of Mediterranean loggerhead sea turtles. Interestingly, the north Adriatic Sea and the Gulf of Gabès are by far the largest areas of continental shelf in the entire Mediterranean and regions of exceptionally high primary productivity (Agostini and Bakun 2002). These areas are therefore probably rich in benthic invertebrates, the main prey of adult loggerhead sea turtles (Bjorndal 1997).

To what extent the conclusions we draw from our data on female spatial behaviour apply to the behaviour of males is difficult to assess with the current lack of data on adult sea turtle male spatial behaviour. Our limited knowledge about the movements of male sea turtles indicates that their spatial behaviour may be similar to that of females (Hays et al. 2001b; Hatase et al. 2002a; James et al. 2005a, b). Certainly, more research into the movements of male turtles is needed for both an increased understanding of the ecological determinants of sea turtle spatial behaviour and the design of effective conservation measures that encompass both sexes.

Six out of the seven tracked turtles migrated along relatively direct routes at cruising speeds of roughly $1.5 \mathrm{~km} / \mathrm{h}$ to neritic foraging areas situated $700-1,200 \mathrm{~km}$ away from their nesting beach. Average foraging area home range size was with $305 \mathrm{~km}^{2}$ comparable to the $331 \mathrm{~km}^{2}$ found by Broderick et al. (2007) for loggerhead sea turtles tracked from Cyprus. Such behaviour seems to be typical for postnesting loggerhead sea turtles globally (Papi et al. 1997; Godley et al. 2002a; Schroeder et al. 2003). The migratory behaviour of female D deviates from this pattern. Its relatively slow movement in the very north of the Adriatic Sea suggests intensive foraging in this neritic region.

In contrast, the extended stay of turtle D in the oceanic area of the Ionian Sea indicates feeding on pelagic prey. 
Table 3 Description of individual foraging and over-wintering areas for six satellite-tracked loggerhead sea turtles

\begin{tabular}{|c|c|c|c|c|c|c|}
\hline Individual & A & B & $\mathrm{C}^{\mathrm{a}}$ & $\mathrm{E}$ & $\mathrm{F}$ & G \\
\hline \multicolumn{7}{|l|}{ Individual foraging area } \\
\hline $\begin{array}{l}\text { Number of locations } \\
\text { (LCs 3, } 2 \text { and 1) }\end{array}$ & 18 & 21 & 12 & 16 & 23 & 36 \\
\hline Median water depth (m) & 17.6 & 27.1 & 2.4 & 31 & 40 & 98.8 \\
\hline $\begin{array}{l}\text { Median distance from } \\
\text { shore }(\mathrm{km})\end{array}$ & 12 & 1 & 0.5 & 6 & 15 & 118.7 \\
\hline $\begin{array}{l}\text { Home range size } \\
\left(\mathrm{MCP} ; \mathrm{km}^{2}\right)\end{array}$ & 100 & 18.5 & 3.5 & 205 & 1,198 & 304 \\
\hline Time period & $\begin{array}{l}20 \text { September to } \\
3 \text { November } \\
2004^{\mathrm{b}}\end{array}$ & $\begin{array}{l}12 \text { September to } \\
31 \text { October } \\
2004^{\mathrm{c}}\end{array}$ & $\begin{array}{l}6 \text { September to } \\
22 \text { November } \\
2004\end{array}$ & $\begin{array}{l}31 \text { August to } \\
8 \text { October } \\
2005\end{array}$ & $\begin{array}{l}5 \text { September to } \\
20 \text { October } \\
2005\end{array}$ & $\begin{array}{l}7 \text { September to } \\
18 \text { November } \\
2005^{\mathrm{d}}\end{array}$ \\
\hline $\begin{array}{l}\text { Minimum water } \\
\text { temperature }\left({ }^{\circ} \mathrm{C}\right)\end{array}$ & - & - & 22.8 & 19.8 & 18.5 & 23.1 \\
\hline \multicolumn{7}{|l|}{ Over-wintering area } \\
\hline $\begin{array}{l}\text { Number of locations } \\
\text { (LCs 3, } 2 \text { and 1) }\end{array}$ & - & - & - & 52 & 1 & - \\
\hline $\begin{array}{l}\text { Distance to individual } \\
\text { main foraging area }(\mathrm{km})\end{array}$ & - & ca. $100^{\mathrm{e}}$ & ca. $250^{\mathrm{e}}$ & 404 & 932 & - \\
\hline Median water depth (m) & - & - & - & 31.2 & - & - \\
\hline $\begin{array}{l}\text { Median distance } \\
\text { from shore }(\mathrm{km})\end{array}$ & - & - & - & 3 & - & - \\
\hline $\begin{array}{l}\text { Home range size } \\
\left(\mathrm{MCP} ; \mathrm{km}^{2}\right)\end{array}$ & - & - & - & 166 & - & - \\
\hline Time period & - & - & - & $\begin{array}{l}27 \text { October } 2005 \\
\text { to } 1 \text { April } \\
2006\end{array}$ & $\begin{array}{l}31 \text { December } 2005 \\
\text { to } 26 \text { April } \\
2006\end{array}$ & - \\
\hline $\begin{array}{l}\text { Minimum water } \\
\text { temperature }\left({ }^{\circ} \mathrm{C}\right)\end{array}$ & - & - & - & 12.6 & 13.7 & - \\
\hline
\end{tabular}

Because of a lack of stratification of the water column in the Mediterranean Sea in winter (Laurent and Lescure 1994; Artegiani et al. 1997; Zotier et al. 1999), the indicated sea surface temperature values are likely to mirror water temperatures experienced by the turtles

MCP mimimum convex polygon

${ }^{a}$ Only first season considered

b Transmissions stopped for unknown reasons on 3 November 2004

${ }^{c}$ Exact date of departure unknown

d Turtle left foraging area, but localisations thereafter unreliable

${ }^{\mathrm{e}}$ Data do not allow exact determination of over-wintering location

Oceanic foraging areas have previously been observed in small-sized adult loggerhead sea turtles of Japan and Cape Verde (Hatase et al. 2002b; Hawkes et al. 2006). The relatively small size of turtle D would fit this pattern, but more research is needed to estimate how widespread oceanic foraging is in Mediterranean loggerhead sea turtles. The fact that turtle D's clutch composition (small clutch size with high number of yolkless eggs) was highly abnormal for Greek loggerhead sea turtles suggests that this female was not yet fully mature and its behaviour may thus generally deviate from that of the majority of adult Mediterranean sea turtles.

Apart from post-nesting migrations and spatial behaviour in foraging areas, we witnessed turtles leaving their foraging areas for more southerly regions in autumn. Such seasonal migrations in the Adriatic Sea were previously suggested based on the observation that turtle bycatch rates decrease in the north-eastern Adriatic Sea in the winter, matching an increase further south (Lazar et al. 2002). One could assume that turtles would react to decreasing temperatures either through spatial behaviour (moving to warmer areas) or through adapting activity and metabolic levels in a given area. The fact that temperatures in the individual over-wintering areas in the Adriatic Sea dropped well below the presumed activity threshold for the species $\left(15^{\circ} \mathrm{C}\right.$; Ogren and McVea 1995) indicates that turtles might be entering dormancy despite having undertaken considerable spatial displacements. Recent research in the Mediterranean has indeed shown that aerobic resting dives may be a common over-wintering strategy for loggerhead sea 
Fig. 2 Seasonal migrations from individual foraging to over-wintering areas. Individual foraging areas are circled, over-wintering areas are marked with hatched circles. a Turtles in the Adriatic Sea. LCs of lesser accuracy than LC A are shown for part of the tracking duration of turtle B (marked with arrows). b Entire migration of individual C. LCs of lesser accuracy than LC A are shown for part of the tracking duration (marked with arrows)
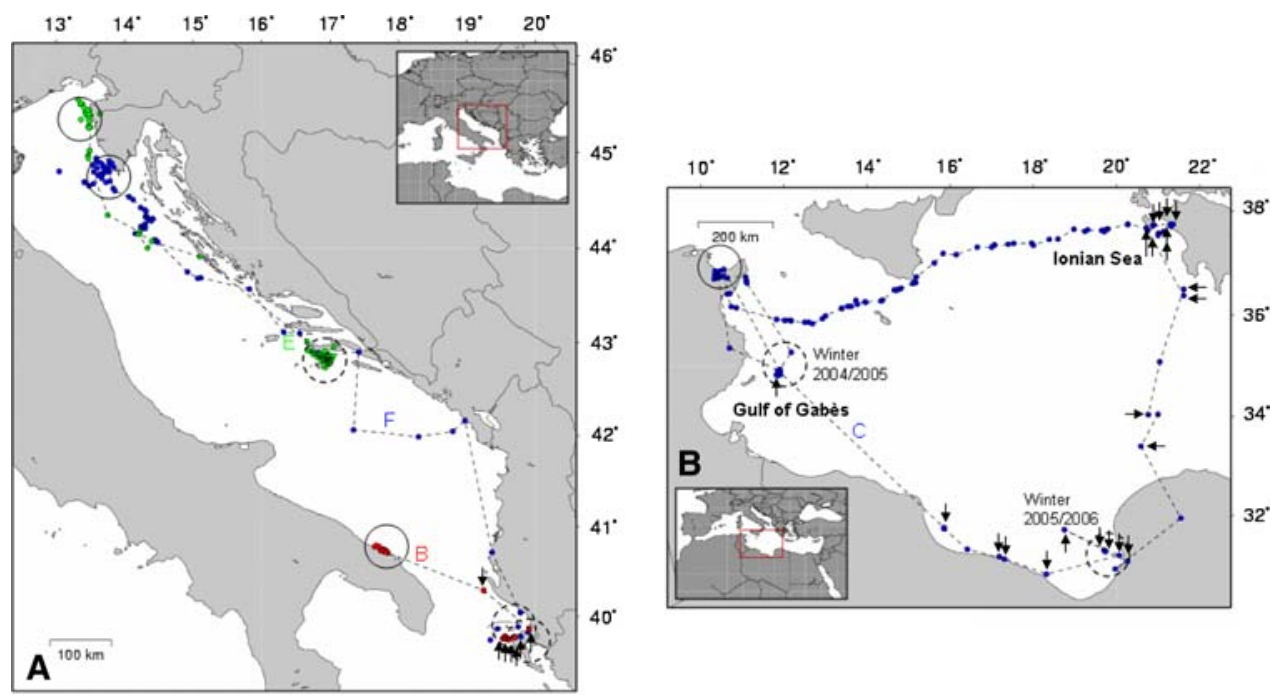

turtles (Hochscheid et al. 2005, 2007). The combination of two wintering strategies suggests that the north Adriatic Sea is a thermally extreme foraging area for loggerhead sea turtles.

The fidelity of the tracked turtles to their individual foraging areas after over-wintering supports the notion of foraging-site fidelity in this species (Limpus et al. 1992; Broderick et al. 2007). However, the turtle tracked during an entire remigration interval spending the winters in two different over-wintering areas suggests that behaviour once preparation for a breeding season has started (Hamann et al. 2003) may differ from that in non-breeding years.

The observed pre-nesting migration and extended seasonal migrations exemplify the complexity of spatial behaviour displayed by adult loggerhead sea turtles, compared to, for example, Mediterranean green sea turtles (Godley et al. 2002b). This pattern fits well into the interspecies gradient of site fidelity ranging from short stays in a particular area as, for example, in leatherback sea turtles (Dermochelys coriacea) to very limited spatial and temporal variation in residence location in green sea turtles, with the behaviour of loggerhead sea turtles laying somewhere along this continuum (Plotkin 2003). Our observations, although limited, further highlight that conclusions on spatial behaviour of at least certain sea turtle species based on satellite tracking data may be incomplete as devices often only allow individuals to be followed for a few months after breeding.

\section{Conclusions}

Our results provide further support for recommendations for concerted conservation efforts in the Adriatic Sea and Gulf of Gabès region. There are reasons to consider both these areas to be imminently important for Mediterranean sea turtles, and not just for adult loggerhead sea turtles from Zakynthos. The north Adriatic Sea is used by large numbers of subadult loggerhead sea turtles (Casale et al. 2004), while the north African coastline was identified as a key foraging area for Mediterranean green sea turtles (Godley et al. 2002b) and is also a foraging area for adult loggerhead sea turtles from the Cyprus rookery (Broderick et al. 2007). Focused protection of these areas is undoubtedly needed, although the complex spatial behaviour revealed in this study suggests that additional measures to reduce detrimental interaction of adult loggerhead sea turtles with fisheries in the eastern Mediterranean basin are likewise required.

Acknowledgments The major part of this research was funded by a grant from the MAVA Foundation for the Protection of Nature. We thank the Karl Mayer Foundation and the Ocean Science and Research Foundation for additional funding provided. We are most grateful to A. Rees for generously sharing practical experience with attaching transmitters. Thanks go to C. Davy, C. Dean and E. Ransome as well as several ARCHELON volunteers for helping with transmitter attachment. K. Grimanis is thanked for having dealt with logistic issues in the study area. Valuable discussions with F. Bontadina and B. Godley helped in the interpretation of results, and comments by C. Davy improved the manuscript. The comments of several anonymous reviewers improved the quality of the paper. We thank F. Bentivegna for returning a transmitter and K. Lay of Sirtrack for excellent customer service. Transmitter attachment was approved by the appropriate Greek authorities.

\section{References}

Agostini VN, Bakun A (2002) 'Ocean triads' in the Mediterranean Sea: physical mechanisms potentially structuring reproductive habitat suitability (with example application to European anchovy, Engraulis encrasicolus). Fish Oceanogr 11:129-142

Artegiani A, Bregant D, Paschini E, Pinardi N, Raicich F, Russo A (1997) The Adriatic Sea general circulation. Part I: air-sea interactions and water mass structure. J Phys Oceanogr 27:1492-1514 
Bjorndal KA (1997) Foraging ecology and nutrition of sea turtles. In: Lutz PL, Musick JA (eds) The biology of sea turtles. CRC Press, Boca Raton, pp 199-231

Bowen BW, Avise JC, Richardson JI, Meylan AB, Margaritoulis D, Hopkins-Murphy SR (1993) Population structure of loggerhead turtles (Caretta caretta) in the northwestern Atlantic Ocean and Mediterranean Sea. Conserv Biol 7:834-844

Broderick AC, Coyne MS, Fuller WJ, Glen F, Godley BJ (2007) Fidelity and over-wintering of sea turtles. Proc R Soc Lond B 274:1533-1538

Casale P, Laurent L, DeMetrio G (2004) Incidental capture of marine turtles by the Italian trawl fishery in the north Adriatic Sea. Biol Conserv 119:287-295

Coyne MS, Godley BJ (2005) Satellite tracking and analysis tool (STAT): an integrated system for archiving, analyzing and mapping animal tracking data. Mar Ecol Prog Ser 301:1-7

Crouse DT, Crowder LB, Caswell H (1987) A stage-based population model for loggerhead sea turtles and implications for conservation. Ecology 68:1412-1423

Gaspar P, Georges J-Y, Fossette S, Lenoble A, Ferraroli S, Maho YL (2006) Marine animal behaviour: neglecting ocean currents can lead us up the wrong track. Proc R Soc Lond B 273:2697-2702

Gerosa G, Casale P (1999) Interaction of marine turtles with fisheries in the Mediterranean. UNEP (MAP), RAC/SPA, Tunis

Godley BJ, Broderick AC, Glen F, Hays GC (2002a) Post-nesting movements and submergence patterns of loggerhead marine turtles in the Mediterranean assessed by satellite tracking. J Exp Mar Biol Ecol 4075:1-16

Godley BJ, Richardson S, Broderick AC, Coyne MS, Glen F, Hays GC (2002b) Long-term satellite telemetry of the movements and habitat utilisation by green turtles in the Mediterranean. Ecography 25:352-363

Hamann M, Limpus CJ, Owens DW (2003) Reproductive cycles of males and females. In: Wyneken $\mathrm{J}$ (ed) The biology of sea turtles, vol 2. CRC Press, Boca Raton, pp 135-161

Hatase H, Matsuzawa Y, Sakamoto W, Baba N, Miyawaki I (2002a) Pelagic habitat use of an adult Japanese male loggerhead turtle Caretta caretta examined by the Argos satellite system. Fish Sci 68:945-947

Hatase H, Takai N, Matsuzawa Y, Sakamoto W, Omuta K, Goto K, Arai N, Fujiwara T (2002b) Size-related differences in feeding habitat use of adult female loggerhead turtles Caretta caretta around Japan determined by stable isotope analysis and satellite telemetry. Mar Ecol Prog Ser 233:273-281

Hawkes LA, Broderick AC, Coyne MS, Godfrey MH, Lopez-Jurado L-F, Lopez-Suarez P, Merino SE, Varo-Cruz N, Godley BJ (2006) Phenotypically linked dichotomy in sea turtle foraging requires multiple conservation approaches. Curr Biol 16:990-995

Hays GC (2004) Good news for sea turtles. Trends Ecol Evol 19:349_ 351

Hays GC, Akesson S, Godley BJ, Luschi P, Santidrian P (2001a) The implications of location accuracy for the interpretation of satellite-tracking data. Anim Behav 61:1035-1040

Hays GC, Broderick AC, Glen F, Godley BJ, Nichols WJ (2001b) The movement and submergence behaviour of male green turtles at Ascension Island. Mar Biol 139:395-399

Hays GC, Broderick AC, Godley BJ, Luschi P, Nichols WJ (2003) Satellite telemetry suggests high levels of fishing-induced mortality in marine turtles. Mar Ecol Prog Ser 262:305-309

Hays GC, Hobson VJ, Metcalfe JD, Righton D, Sims DW (2006) Flexible foraging movements of leatherback turtles across the north Atlantic ocean. Ecology 87:2647-2656

Heppell SS, Snover ML, Crowder LB (2003) Sea turtle population ecology. In: Wyneken J (ed) The biology of sea turtles. CRC Press, Boca Raton, pp 275-298
Hochscheid S, Bentivegna F, Hays GC (2005) First records of dive durations for a hibernating sea turtle. Biol Lett 1:82-86

Hochscheid S, Bentivegna F, Bradai MN, Hays GC (2007) Over-wintering in sea turtles: dormancy is optional. Mar Ecol Prog Ser 340:287-298

James MC, Eckert SA, Myers RA (2005a) Migratory and reproductive movements of male leatherback turtles (Dermochelys coriacea). Mar Biol 147:845-853

James MC, Myers RA, Ottensmeyer CA (2005b) Behaviour of leatherback sea turtles, Dermochelys coriacea, during the migratory cycle. Proc R Soc Lond B 272:1547-1555

Laurent L, Lescure J (1994) L'hivernage des tortues caouannes Caretta caretta (L.) dans le sud Tunesien. Rev d'Ecol (Terre et Vie) 49:63-86

Laurent L, Lescure J, Excoffier L, Bowen B, Domingo M, Hadjichristophorou M, Kornaraki L, Trabuchet G (1993) Etude Génétique des relations entre les populations méditerranéenne et atlantique d'une tortue marine (Caretta caretta) à l'aide d'un marqueur mitochondrial. C R Acad Sci Paris 316:1233-1239

Laurent L, Casale P, Bradai MN, Godley BJ, Gerosa G, Broderick AC, Schroth W, Schierwater B, Levy AM, Freggi D, El-Mawla EMA, Hadoud DA, Gomati HE, Domingo M, Hadjichristophorou M, Kornaraky L, Demirayak F, Gautier C (1998) Molecular resolution of marine turtle stock composition in fishery bycatch: a case study in the Mediterranean. Mol Ecol 7:1529-1542

Lazar B, Borboroglu PG, Tvrtkovic N, Ziza V (2002) Temporal and spatial distribution of the loggerhead sea turtle Caretta caretta in the eastern Adriatic Sea: a seasonal migration pathway? In: Seminoff JA (ed) 22nd annual symposium on sea turtle biology and conservation. NOAA Technical Memorandum, Miami, pp 283284

Lewison RL, Freeman SA, Crowder LB (2004) Quantifiying the effects of fisheries on threatened species: the impact of pelagic longlines on loggerhead and leatherback sea turtles. Ecol Lett 7:221-231

Limpus CL, Miller JD, Parmenter CJ, Reimer D, McLachlan N, Webb R (1992) Migration of green (Chelonia mydas) and loggerhead (Caretta caretta) turtles to and from eastern Australian rookeries. Wildl Res 19:347-358

Luschi P, Hays GC, DelSeppia C, Marsh R, Papi F (1998) The navigational feats of green sea turtles migrating from Ascension Island investigated by satellite telemetry. Proc R Soc Lond B 265:22792284

Margaritoulis D, Argano R, Baran I, Bentivegna F, Bradai MN, Camiñas JA, Casale P, Metrio GD, Demetropoulos A, Gerosa G, Godley BJ, Haddoud DA, Houghton J, Laurent L, Lazar B (2003) Loggerhead turtles in the Mediterranean Sea: present knowledge and conservation perspectives. In: Witherington BE (ed) Loggerhead sea turtles. Smithsonian Institution, Washington, pp 175198

McMahon CR, Bradshaw CJA, Hays GC (2007) Satellite tracking reveals unusual diving characteristics for a marine reptile, the olive ridley turtle Lepidochelys olivacea. Mar Ecol Prog Ser 329:239_ 252

Myers AE, Hays GC (2006) Do leatherback turtles Dermochelys coriacea forage during the breeding season? A combination of data-logging devices provide new insights. Mar Ecol Prog Ser 322:259-267

Ogren L, McVea CJ (1995) Apparent hibernation by sea turtles in North American waters. In: Bjorndal KA (ed) Biology and conservation of sea turtles. Smithsonian Institution Press, Washington, pp 127-132

Papi F, Luschi P, Crosio E, Hughes GH (1997) Satellite tracking experiments on the navigational ability and migratory behaviour of the loggerhead turtle Caretta caretta. Mar Biol 129:215-220 
Plotkin PT (2003) Adult migrations and habitat use. In: Wyneken J (ed) The Biology of sea turtles. CRC Press, Boca Raton, pp 225241

Schroeder BA, Foley AM, Bagley DA (2003) Nesting patterns, reproductive migrations, and adult foraging areas of loggerhead turtles. In: Witherington BE (ed) Loggerhead sea turtles. Smithsonian Books, Washington, pp 114-124

Spotila JR, Reina RD, Steyermark AC, Plotkin PT, Paladino FV (2000) Pacific leatherback turtles face extinction. Nature 405:529-530
Tiwari M, Bjorndal KA (2000) Variation in morphology and reproduction in loggerheads, Caretta caretta, nesting in the United States, Brazil, and Greece. Herpetologica 56:343-356

Troëng S, Evans DR, Harrison E, Lagueux CJ (2005) Migration of green turtles Chelonia mydas from Tortuguero, Costa Rica. Mar Biol 148:435-447

Zavatarelli M, Pinardi N (2003) The Adriatic Sea modelling system: a nested approach. Ann Geophys 21:345-364

Zotier R, Bretagnolle V, Thibault J-C (1999) Biogeography of the marine birds of a confined sea, the Mediterranean. J Biogeogr 26:297-313 